\title{
Comparison of mechanical properties of $\mathrm{Fe}-1 \cdot 75 \mathrm{Ni}-0 \cdot 5 \mathrm{Mo}-1 \cdot 5 \mathrm{Cu}-0 \cdot 4 \mathrm{C}$ steels made from PIM and press and sinter processes
}

\author{
K. S. Hwang, C. H. Hsieh, and G. J. Shu
}

Powder injection moulding (PIM) is a relatively new process and only a few alloy standards have been recognised. To further promote the application of this technology, new alloys with competitive mechanical properties need to be developed. $\mathrm{Fe}-1 \cdot 75 \mathrm{Ni}-0 \cdot 5 \mathrm{Mo}-$ $1.5 \mathrm{Cu}-\mathrm{xC}$ is one of the compositions widely used in the conventional powder metallurgy industry in making press and sinter parts. To benefit from the excellent mechanical properties and the accumulated knowledge of this alloy system, the same composition was employed in this study to make powder injection moulded compacts with the expectation that even better mechanical properties would be attained. The results obtained on the compacts sintered at $1200^{\circ} \mathrm{C}$ for $1 \mathrm{~h}$ showed a tensile strength, hardness, and elongation of $685 \mathrm{MPa}, 91 \mathrm{HRB}$, and $7 \cdot 5 \%$ respectively. With heat treatment, the tensile strength and hardness increased to $1530 \mathrm{MPa}$ and $52 \mathrm{HRC}$, respectively. However, the elongation decreased to less than $1.0 \%$. These properties are better than those of the press and sinter counterparts owing to higher sintered density, finer grain size, and more homogeneous microstructure.

$\mathrm{PM} / 0976$

The authors (kshwang@ccms.ntu.edu.tw) are at the Institute of Materials Science and Engineering, National Taiwan University, No. 1, Roosevelt Rd., Sec. 4, Taipei 106, Taiwan. Manuscript received 21 August 2001; accepted 23 January 2002.

(C) 2002 IoM Communications Ltd.

\section{INTRODUCTION}

Powder injection moulding (PIM) is an effective manufacturing process in making complex shaped parts with little or no secondary machining. The sintered density is usually greater than $95 \%$, a level that cannot be attained with the conventional press and sinter technique unless liquid phase sintering occurs. The PIM process, however, has its limitations owing to its relatively new position in the manufacturing industry. One such limitation is that, unlike in the matured wrought processes, such as investment casting, only a few standard alloys are used in the industry. To further advance the application of PIM structural parts, new alloys with improved mechanical properties must be developed. This need has been addressed by several recent studies. $^{2-5}$

Over the long history of the powder metallurgy (PM) process, a large number of alloy systems have been developed for press and sinter parts. One of them is $\mathrm{Fe}-1 \cdot 75 \mathrm{Ni}-0.5 \mathrm{Mo}-$ $1 \cdot 5 \mathrm{Cu}-\mathrm{xC}$, which is designated as FD-0205 by the Metal Powder Industries Federation. ${ }^{6-9}$ The main alloying element is nickel, which is added to improve the hardenability. It also enhances sintering by impeding the grain growth and by increasing the grain boundary diffusion rate. ${ }^{10-13}$ However, owing to the formation of large pores near the original sites of the nickel particles, these benefits diminish when the amount of nickel exceeds $2 \mathrm{wt}-\%{ }^{10,11}$ Nickel also forms nickel rich martensite after heat treatment, which can retard the crack propagation when fatigue occurs. ${ }^{1 .}$

Copper is a $\gamma$ phase stabiliser, like nickel, and is also an alloying element effective in increasing the hardenability of iron. Its main strengthening mechanism is solid solution hardening. ${ }^{15,16}$ After quenching and aging, the mechanical properties can be further improved by precipitation hardening.

Molybdenum is also another good hardenability promoter. ${ }^{82-22}$ When prealloyed into iron powders, it does not impair the compressibility and thus can be used in the prealloyed form in making press and sinter parts. It also has a high diffusion rate into iron, which helps improve the uniformity of the microstructure and the mechanical properties.

Although FD-0205 is a well accepted alloy in the conventional PM industry, and a large database on processing parameters and mechanical properties is available, little information has been reported on PIM parts made from such an alloy system. It is reasonable to expect that the properties of PIM parts will be further improved owing to the fineness of the iron powders used, a characteristic that usually helps the compact to achieve higher sintered density and better alloying. The objective of this study was thus to compare the mechanical properties of $\mathrm{Fe}-1.75 \mathrm{Ni}-$ $1 \cdot 5 \mathrm{Cu}-0.5 \mathrm{Mo}-\mathrm{xC}$ specimens made by the press and sinter technique and by the PIM process.

\section{EXPERIMENTAL PROCEDURE}

A carbonyl iron powder with an average particle size of $4.6 \mu \mathrm{m}$ (Fisher subsieve size) was selected as the base powder in this study. The carbon and oxygen content were 0.79 and $0.81 \mathrm{wt}-\%$, respectively. Since the oxygen will react with the intrinsic carbon, in addition to the reaction with the organic binder, such as polyethylene used in this study, decarburisation will occur during the process. However, there was still a considerable amount of carbon left in the iron powder to contribute to the strength of sintered compacts. The characteristics of this powder are given in Table 1. Nickel, copper, and molybdenum elemental powders were added at $1 \cdot 75,1 \cdot 5$, and $0.50 \mathrm{wt}-\%$, respectively. Table 2 and Fig. 1 show the characteristics and the morphology of these alloying powders.

For feedstock preparation, elemental powders of Fe, $\mathrm{Ni}, \mathrm{Mo}$, and $\mathrm{Cu}$ were properly weighed and mixed in a $\mathrm{V}$ shaped mixer. The mixed powder was kneaded with a multicomponent binder consisting of polyethylene, stearic acid, and paraffin wax. The kneaded feedstock was then injection moulded into $85.5 \mathrm{~mm}$ long tensile test specimens (MPIF Standard 50) using barrel, nozzle, and mould temperatures of 135,140 , and $40^{\circ} \mathrm{C}$, respectively. To remove the binder, moulded specimens were immersed in a $40^{\circ} \mathrm{C}$ 


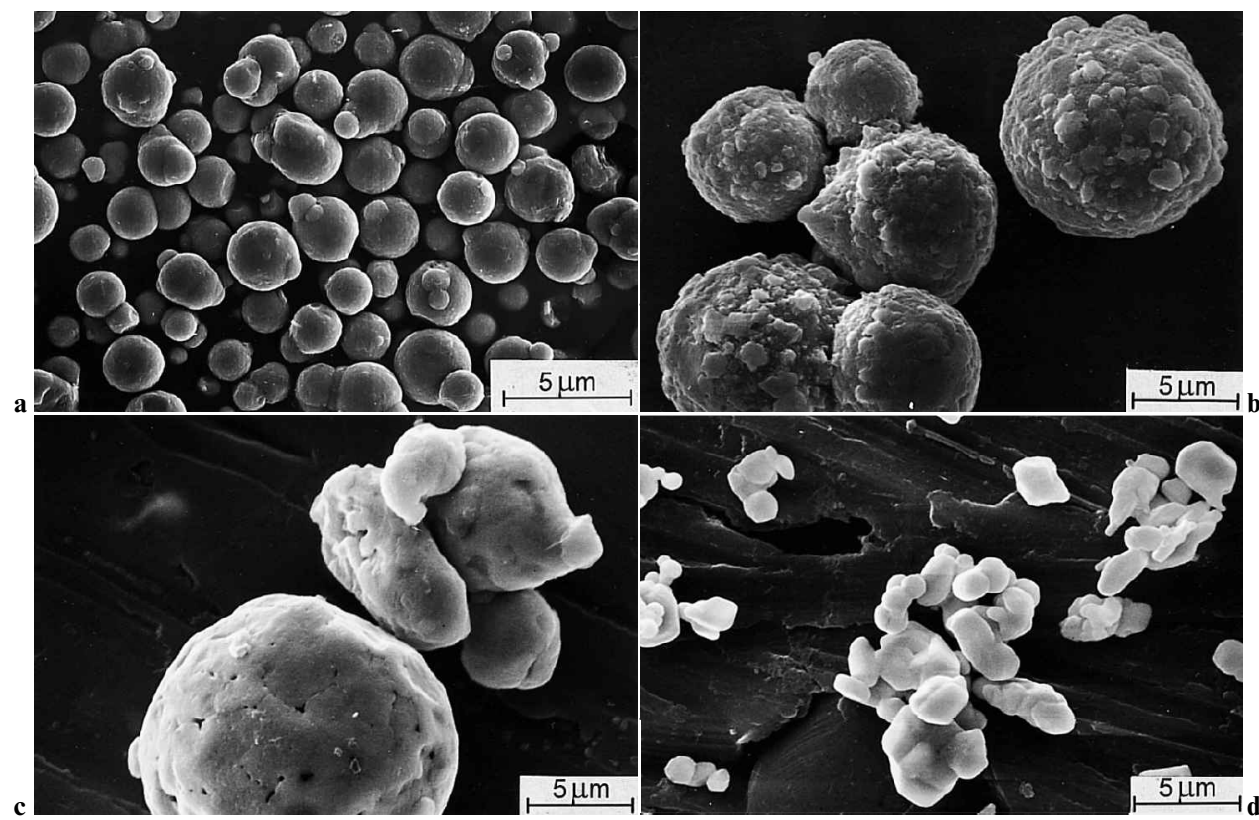

$a$ iron; $b$ nickel; $c$ copper; $d$ molybdenum

1 Morphology of metal powders used in present study

heptane bath for $4 \mathrm{~h}$ to extract $90 \%$ of the soluble binders. The remaining binder was removed during the subsequent thermal debinding step by heating the specimen at a rate of $10 \mathrm{~K} \mathrm{~min}^{-1}$ to $800^{\circ} \mathrm{C}$. The debinding atmosphere used was $\mathrm{N}_{2}-\mathrm{xH}_{2}$ with $\mathrm{x}$ values being $0,30,40,50,60,70$, and $100 \%$. Sintering was carried out under $95 \mathrm{~N}_{2}-5 \mathrm{H}_{2}$ for $1 \mathrm{~h}$ at 1100,1200 , and $1250^{\circ} \mathrm{C}$. The heating rate employed was also $10 \mathrm{~K} \mathrm{~min}^{-1}$. For heat treatment, specimens were austenised at $850^{\circ} \mathrm{C}$ for $30 \mathrm{~min}$ in argon, oil quenched, and then tempered at $175^{\circ} \mathrm{C}$ for $60 \mathrm{~min}$.

To understand the effect of alloying elements on the sintering behaviour of iron, the microstructures of sintered compacts were analysed. A thermal dilatometer (Dilatronic II, Theta, Port Washington, NY, USA) was also employed to compare the sintering curve of this alloy with that of the pure iron. These specimens were solvent debound first and then heated to $700^{\circ} \mathrm{C}$ for thermal debinding, prior to the

Table 1 Characteristics of carbonyl iron powder used in present study

$\begin{array}{ll}\begin{array}{l}\text { Designation } \\ \text { Supplier }\end{array} & \begin{array}{l}\text { Carbonyl iron powder (CIP-S-1641) } \\ \text { Average particle size }\end{array} \\ \begin{array}{l}\text { ISP Corp, Wayner) } \\ 4.6 \mu \mathrm{m}\end{array} \\ \text { Surface area (BET) } & 0.77 \mathrm{~m}^{2} \mathrm{~g}^{-1} \\ \text { Pycnometer density } & 7.542 \mathrm{~g} \mathrm{~cm}^{-3} \\ \text { Angle of repose } & 50^{\circ} \\ \text { Tap density } & 4.16 \mathrm{~g} \mathrm{~cm}^{-3} \\ \text { Chemistry, wt-\% C } & 0.79 \\ \text { O } & 0.81 \\ \text { N } & 0.72\end{array}$

Table 2 Characteristics of $\mathrm{Ni}$, Mo, and $\mathrm{Cu}$ powders used in present study

\begin{tabular}{lllll}
\hline & Designation & Supplier & $\begin{array}{l}\text { Particle size } \\
(\mathrm{FSSS}), \mu \mathrm{m}\end{array}$ & $\begin{array}{l}\text { Angle of } \\
\text { repose, deg }\end{array}$ \\
\hline $\mathrm{Ni}$ & $\mathrm{Ni}-4 \mathrm{SP}$ & Inco & $6 \cdot 4$ & 50 \\
$\mathrm{Mo}$ & OMP-860 & H. C. Starck & $2 \cdot 3$ & 54 \\
$\mathrm{Cu}$ & 635 & ACu Powder & $8 \cdot 7$ & 34 \\
\hline
\end{tabular}

dilatometer run. The dilatometer tests were carried out using the same heating rate, holding temperature, and atmosphere as those employed for the sintering runs.

To analyse the homogeneity of alloying elements, an electron probe microanalyser (JXA-8600SX, Jeol Co., Tokyo, Japan) was used to measure the composition distribution in the matrix. The carbon content was measured with a carbon analyser (CS-244, LECO Co., St. Joseph, MI, USA). The tensile test was performed using a strain rate of $1.0 \times 10^{-3} \mathrm{~s}$.

\section{RESULTS}

\section{Effect of atmosphere on carbon content}

The carbon content of the specimens prepared in this study was aimed at $0.4 \%$. It was noticed that the use of atmospheres with different amounts of hydrogen resulted in different carbon contents and sintered densities. Figure 2 illustrates that the carbon content in the debound compact increased first, reaching a maximum, and then decreased

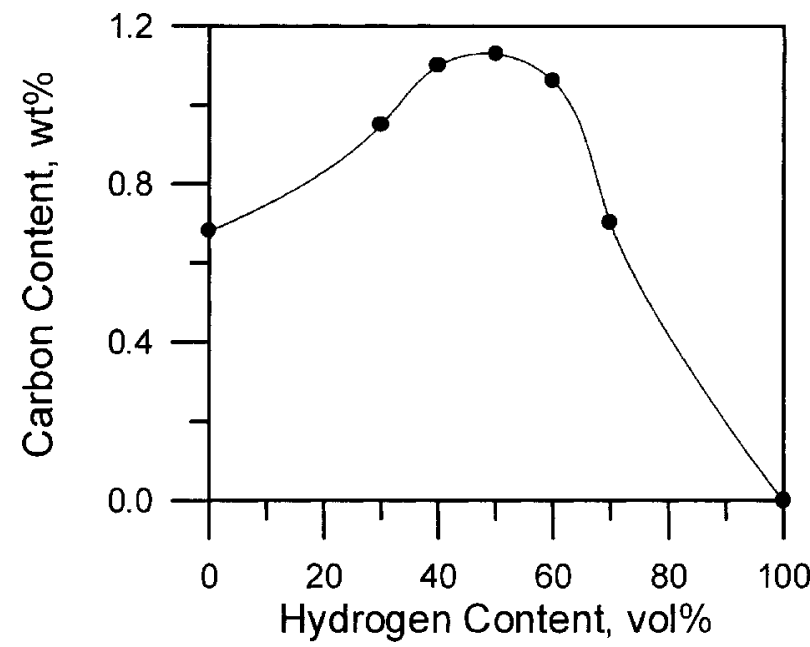

2 Carbon content in debound compact increases and then decreases as hydrogen content in debinding atmosphere increases 
as the amount of hydrogen in the debinding atmosphere increased. The maximum carbon content was attained by using 40-60\% hydrogen. Similar findings and the reasons for this have been reported in previous literature. ${ }^{23,24}$ When these debound compacts were sintered in $95 \mathrm{~N}_{2}-5 \mathrm{H}_{2}$, the carbon content further decreased. Table 3 shows that as the carbon content increases, the sintered density is improved. Since the targeted $0.4 \%$ carbon was obtained by debinding first under the $60 \mathrm{~N}_{2}-40 \mathrm{H}_{2}$ atmosphere and followed by sintering under $95 \mathrm{~N}_{2}-5 \mathrm{H}_{2}$, the specimens needed for the measurement of mechanical properties were all produced using these parameters.

\section{Microstructure}

Figure 3 shows the microstructure of compacts sintered for $1 \mathrm{~h}$ in $95 \mathrm{~N}_{2}-5 \mathrm{H}_{2}$ at 1100,1200 , and $1250^{\circ} \mathrm{C}$, respectively. As the sintering temperature increased, the grain size increased slightly. Figure $3 b$ shows that the compact consisted of ferrite, bainite, and martensite. The ferrite appears as the white areas with clear grain boundaries. The grey areas contain bainite. Some martensite appeared in the lightly etched areas which are enriched with nickel. The microhardness measured at the locations of ferrite, bainite, and martensite were, in sequential order, $158 \mathrm{HV}, 250 \mathrm{HV}$, and $332 \mathrm{HV}$.

The electron probe microanalysis carried out on the sintered compact, as illustrated in Fig. 4, shows that the martensite areas with characteristic lath structures were enriched with $\mathrm{Ni}$. In contrast, $\mathrm{Mo}$ and $\mathrm{Cu}$ were more uniformly distributed. As the sintering temperature increased, the degree of homogenisation of $\mathrm{Ni}, \mathrm{Cu}$, and Mo improved, as was indicated by the line scan.

After being austenised at $850^{\circ} \mathrm{C}$ for $30 \mathrm{~min}$, oil quenched, and then tempered at $175^{\circ} \mathrm{C}$ for $1 \mathrm{~h}$, the microstructure, as shown in Fig. 5, became more uniform. It consisted mainly of martensite and a small amount of bainite. No retained austenite was present, as was confirmed by the X-ray diffraction patterns.

\section{Dilatometer analysis}

Figure $6 a$ illustrates the dilatometric curves of $\mathrm{Fe}-1 \cdot 75 \mathrm{Ni}-$ $1.5 \mathrm{Cu}-0.5 \mathrm{Mo}$ compacts under pure hydrogen and $95 \mathrm{~N}_{2}-5 \mathrm{H}_{2}$, respectively. The derivatives of the two curves are shown in Fig. $6 b$. Both specimens show a little dip in shrinkage rate around $740^{\circ} \mathrm{C}$. This indicated that a small portion of the compact transformed into $\gamma$ phase at $740^{\circ} \mathrm{C}$, probably owing to the presence of $\gamma$ phase stabilisers, particularly the intrinsic carbon.

When pure hydrogen was employed, the compact showed another drop in shrinkage rate at $910^{\circ} \mathrm{C}$. This is most likely caused by the phase transformation of the decarburised iron. After the phase transformation, the shrinkage rate slowed down significantly because of the slow diffusion rate in the $\gamma$ phase and the exaggerated grain growth which occurred during the $\alpha \rightarrow \gamma$ phase transformation. ${ }^{25}$ In contrast, when specimens were heated under $95 \mathrm{~N}_{2}-5 \mathrm{H}_{2}$, they exhibited little change in the shrinkage rate through $910^{\circ} \mathrm{C}$, as shown in Fig. $6 b$. This suggested that some carbon was retained in the iron owing to the incomplete decarburisation. With more carbon in the iron, the phase transformation

Table 3 Carbon content and its effect on sintered density of compacts that were debound under $100 \% \mathrm{H}_{2}$, $\mathrm{N}_{2}-70 \% \mathrm{H}_{2}$, and $\mathrm{N}_{2}-40 \% \mathrm{H}_{2}$

\begin{tabular}{lll}
\hline Debinding atmosphere & $\begin{array}{l}\text { Carbon content, } \\
\text { wt- } \%\end{array}$ & $\begin{array}{l}\text { Sintered density, } \\
\mathrm{g} \mathrm{cm}^{-3}\end{array}$ \\
\hline $100 \% \mathrm{H}_{2}$ & $0 \cdot 003$ & $7 \cdot 03$ \\
$\mathrm{~N}_{2}-70 \% \mathrm{H}_{2}$ & $0 \cdot 3$ & $7 \cdot 41$ \\
$\mathrm{~N}_{2}-40 \% \mathrm{H}_{2}$ & $0 \cdot 4$ & $7 \cdot 43$ \\
\hline
\end{tabular}

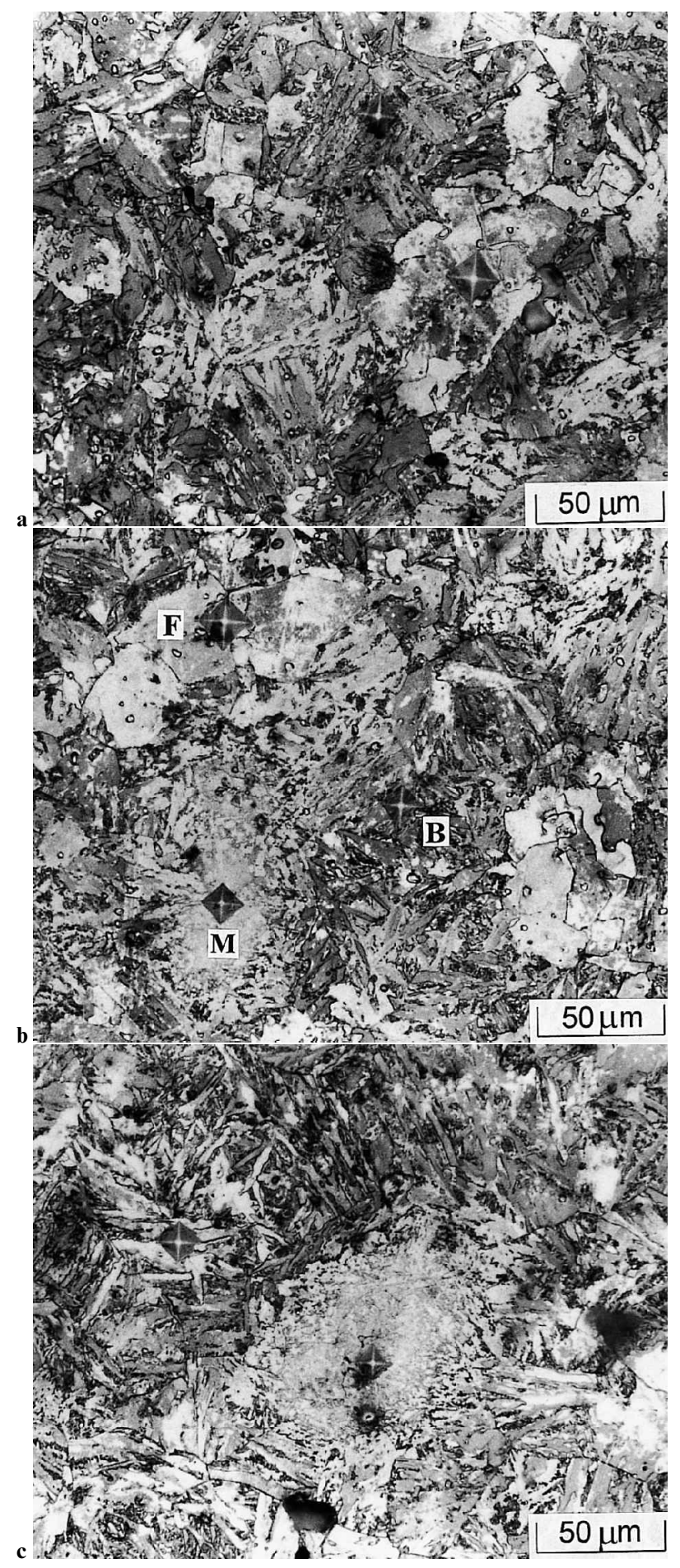

a $1100^{\circ} \mathrm{C} ; b 1200^{\circ} \mathrm{C} ; c 1250^{\circ} \mathrm{C}$

3 Microstructures of injection moulded $\mathrm{Fe}-1 \cdot 75 \mathrm{Ni}-1 \cdot 5 \mathrm{Cu}-$ $0 \cdot 5 \mathrm{Mo}-0 \cdot 4 \mathrm{C}$ compacts sintered at various temperatures

occurred at lower temperatures. Moreover, as a result of the incomplete decarburisation, the carbon distribution is not uniform from the surface to the core of the powders. Thus, the phase transformation occurred in a temperature range, not at a fixed temperature. Thus, no exaggerated grain growth occurred during the $\alpha \rightarrow \gamma$ phase transformation and the sintering rate did not decrease through $910^{\circ} \mathrm{C}$.

To further confirm the effect of carbon, a $\mathrm{Fe}-1 \cdot 75 \mathrm{Ni}-$ $1.5 \mathrm{Cu}-0.5 \mathrm{Mo}$ and a straight carbonyl iron specimen were decarburised during debinding using pure hydrogen prior to the dilatometer run. The carbon content of both compacts decreased to $0.003 \mathrm{wt}-\%$ after debinding. Both 


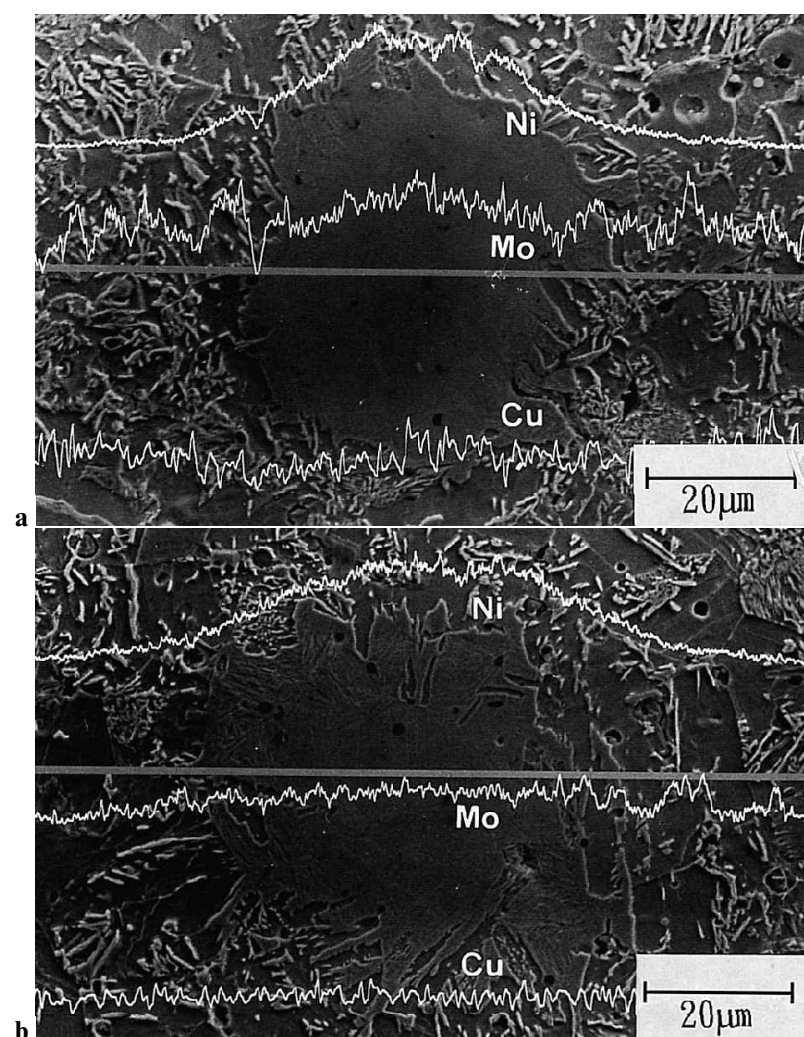

$a 1100^{\circ} \mathrm{C} ; b 1250^{\circ} \mathrm{C}$

4 Line scan showing that $\mathrm{Ni}$ is not as homogenised as Mo and $\mathrm{Cu}$, and that homogenisation improves as sintering temperature increases

shrinkage curves in Fig. 7 show that the deflection occurs at $910^{\circ} \mathrm{C}$, and the deflections of these two curves are more pronounced than those shown in Fig. 6. Since nickel, copper, and molybdenum contents were the same as that in the carbon containing material analysed in Fig. 6, this result indicated that carbon content is the deciding factor in influencing the phase transformation temperature.

\section{Mechanical properties}

Figures 8, 9, 10, and 11 show, respectively, the density, elongation, hardness, and tensile strength of as sintered and heat treated specimens. In the as sintered condition,

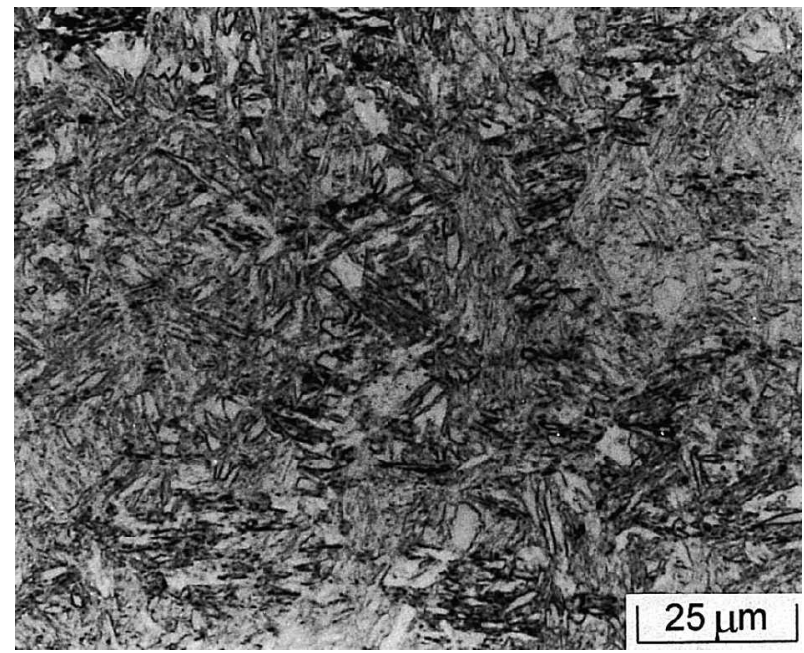

5 Microstructure of injection moulded $\mathrm{Fe}-1 \cdot 75 \mathrm{Ni}-1 \cdot 5 \mathrm{Cu}-$ $0 \cdot 5 \mathrm{Mo}-0 \cdot 4 \mathrm{C}$ compact, sintered at $1200^{\circ} \mathrm{C}$ and then heat treated
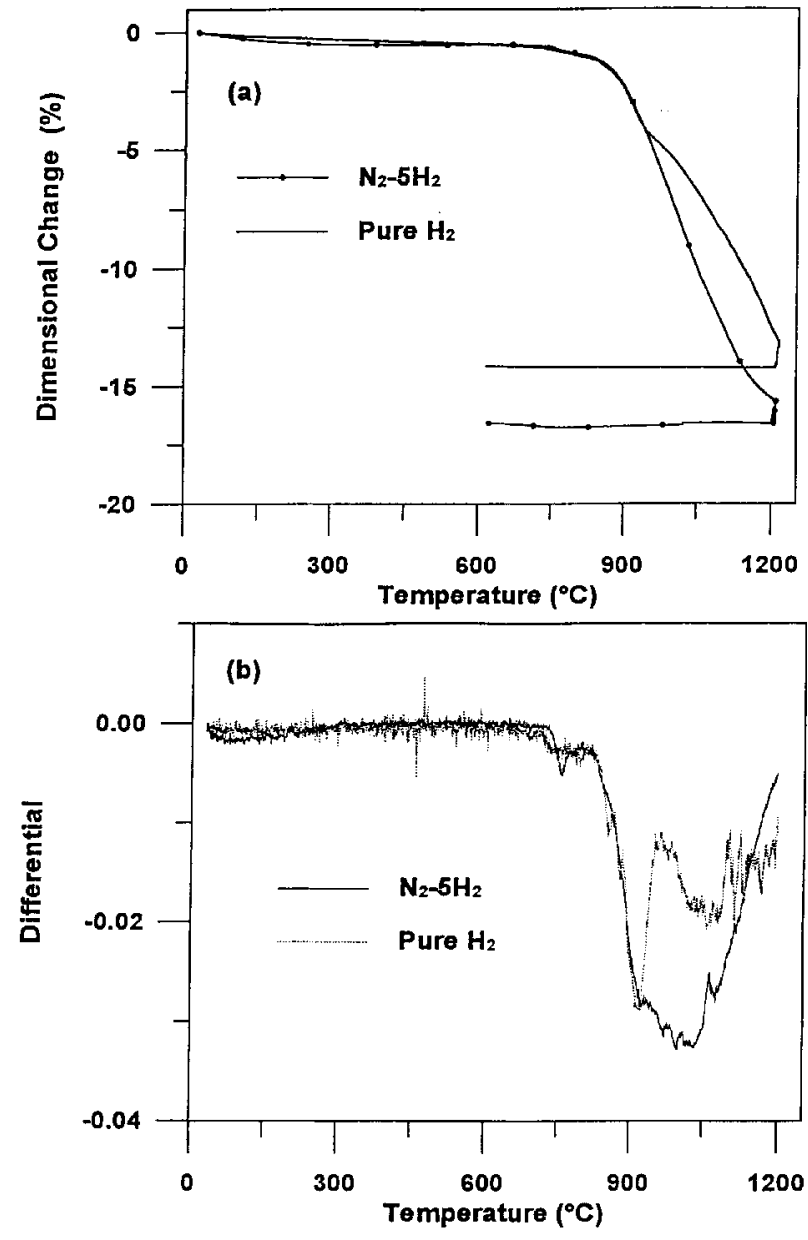

$6 a$ dilatometer curves of $\mathrm{Fe}-1 \cdot 75 \mathrm{Ni}-1 \cdot 5 \mathrm{Cu}-0 \cdot 5 \mathrm{Mo}-\mathrm{xC}$ compacts sintered in pure hydrogen and in $95 \mathrm{~N}_{2}-5 \mathrm{H}_{2}$; $b$ derivatives of two dilatometer curves

the density and elongation increased as the sintering temperature increased. However, the maximum hardness of $91 \mathrm{HRB}$ and the maximum tensile strength of $685 \mathrm{MPa}$ were obtained not at $1250^{\circ} \mathrm{C}$, but at $1200^{\circ} \mathrm{C}$. The lower hardness and strength at $1250^{\circ} \mathrm{C}$ were mainly caused by the grain coarsening effect, similar to the findings reported by Zhang et al. on $\mathrm{Fe}-\mathrm{Ni}$ alloys. ${ }^{26}$

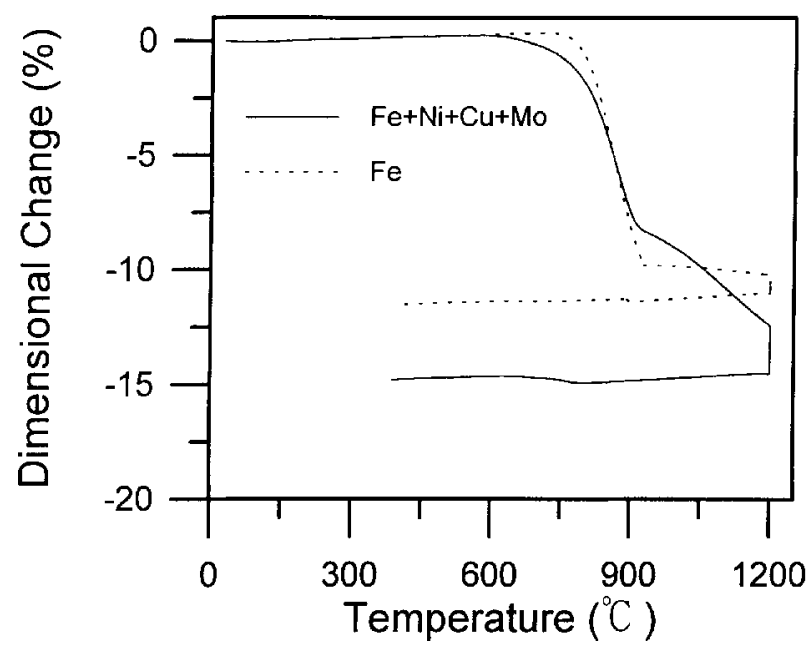

7 Dilatometer curves of decarburised carbonyl iron and $\mathrm{Fe}-1 \cdot 75 \mathrm{Ni}-1 \cdot 5 \mathrm{Cu}-0.5 \mathrm{Mo}$ specimens when heated in $\mathbf{9 5} \mathrm{N}_{2}-5 \mathrm{H}_{2}$ 


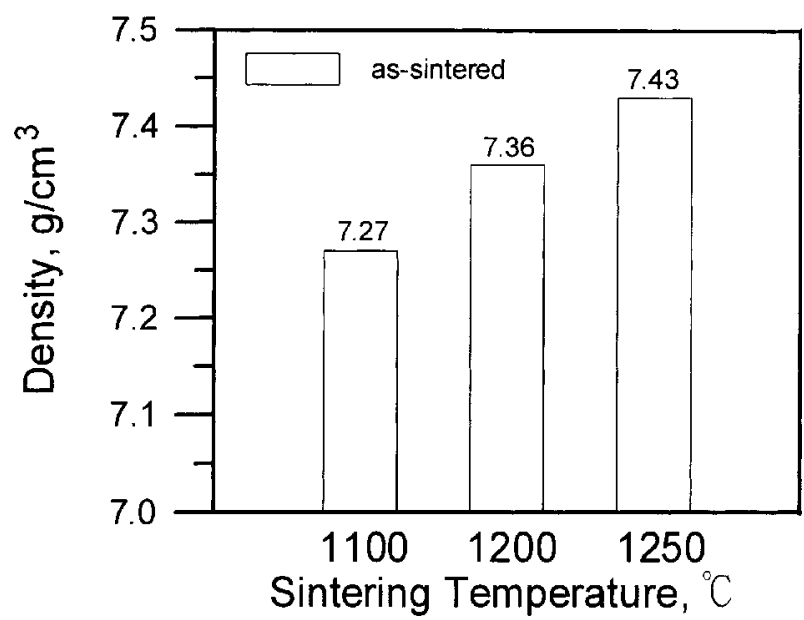

8 Densities of compacts sintered at 1100,1200 , and $1250^{\circ} \mathrm{C}$

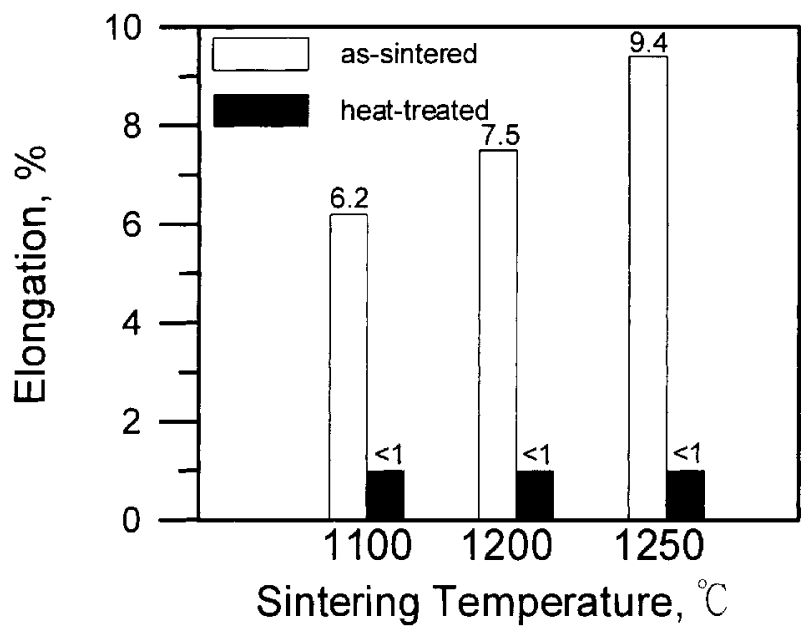

9 Elongation of compacts sintered at 1100, 1200, and $1250^{\circ} \mathrm{C}$

After heat treatment, the tensile strength increased to 1750 and $1530 \mathrm{MPa}$ on compacts sintered at 1250 and $1200^{\circ} \mathrm{C}$, respectively. This indicated that the grain coarsening effect, which deteriorates the strength and hardness of compacts sintered at $1250^{\circ} \mathrm{C}$, diminished owing to the phase which changes occurred during heat treatment. Since there was no grain coarsening effect and the alloy homogenisation improved as the sintering temperature increased, the tensile strength of heat treated parts were enhanced by high temperature sintering. The only drawback was that

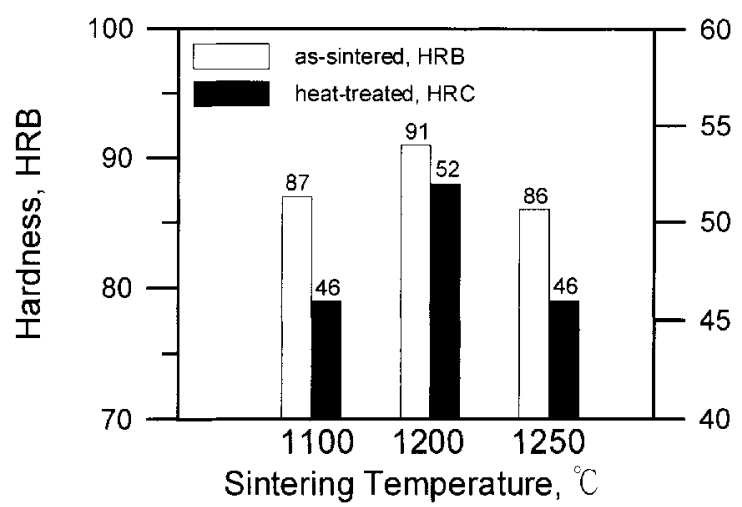

10 Hardness of compacts sintered at 1100, 1200, and $1250^{\circ} \mathrm{C}$

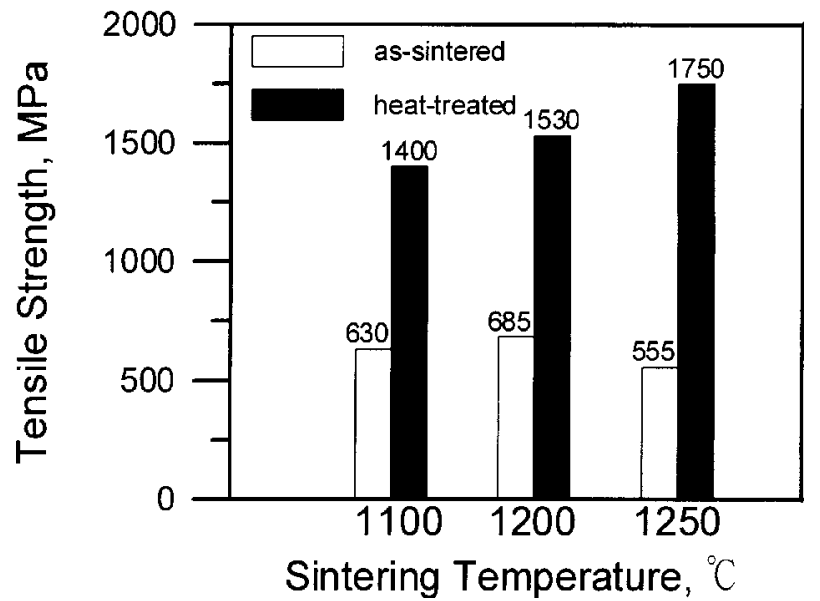

11 Tensile strengths of compacts sintered at 1100, 1200, and $1250^{\circ} \mathrm{C}$

the elongation of all specimens decreased to less than $1 \%$. This could, however, be improved by adjusting the tempering temperature. Figure 12 shows that when specimens were tempered at 275 and $375^{\circ} \mathrm{C}$, the elongation increased to $2 \cdot 0$ and $2.4 \%$, respectively, while the strengths decreased to about $1200 \mathrm{MPa}$.

\section{DISCUSSION}

Table 4 compares the mechanical properties of the $\mathrm{Fe}-1 \cdot 75 \mathrm{Ni}$ $1 \cdot 5 \mathrm{Cu}-0.5 \mathrm{Mo}-\mathrm{xC}$ specimens made from the PIM and the conventional press and sinter processes. In the as sintered condition, the most significant difference between the compacts with similar density levels is that the elongation of the PM specimen is lower than its PIM counterpart. This is probably because of its coarser grain size, larger pore size, and the less homogeneous microstructure, as shown in Fig. 13a. However, irrespective of the inhomogeneous microstructure, which is caused by the longer diffusion distance resulting from the coarser powder used, the tensile strength and hardness values of press and sinter parts are similar to those of the PIM specimens. The reason could be that, in press and sinter parts, high alloy contents were present at pore surfaces and at neck areas. As an example, the nickel mapping in Fig. 14 demonstrates that the nickel content is higher near the pore areas than in the bulk. Since these regions, which are highly stressed, are now heavily alloyed, the apparent strength and hardness are thus improved and are comparable to those of the PIM parts.

After heat treatment, the strength of the PIM specimens sintered at $1200^{\circ} \mathrm{C}$ increased from 685 to $1530 \mathrm{MPa}$, while

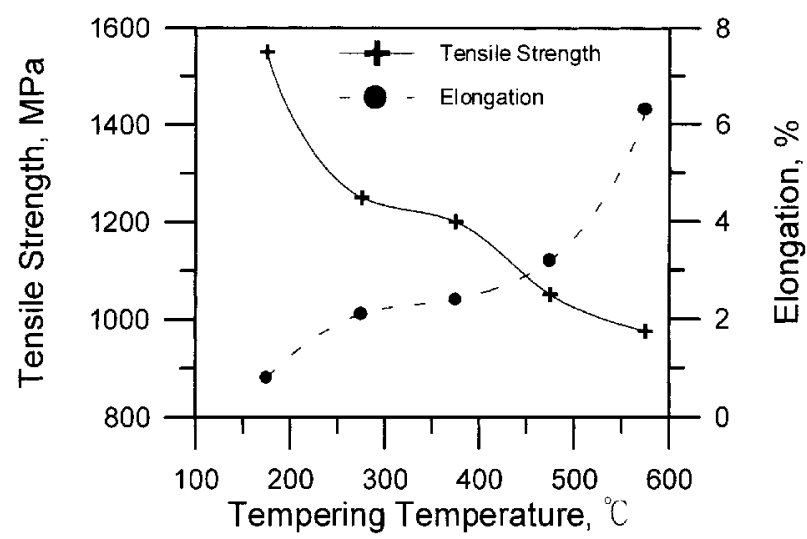

12 As tempering temperature increases, elongation of quenched $\mathrm{Fe}-1 \cdot 75 \mathrm{Ni}-1 \cdot 5 \mathrm{Cu}-0 \cdot 5 \mathrm{Mo}-0 \cdot 4 \mathrm{C}$ compact increases, but with decrease in tensile strength 


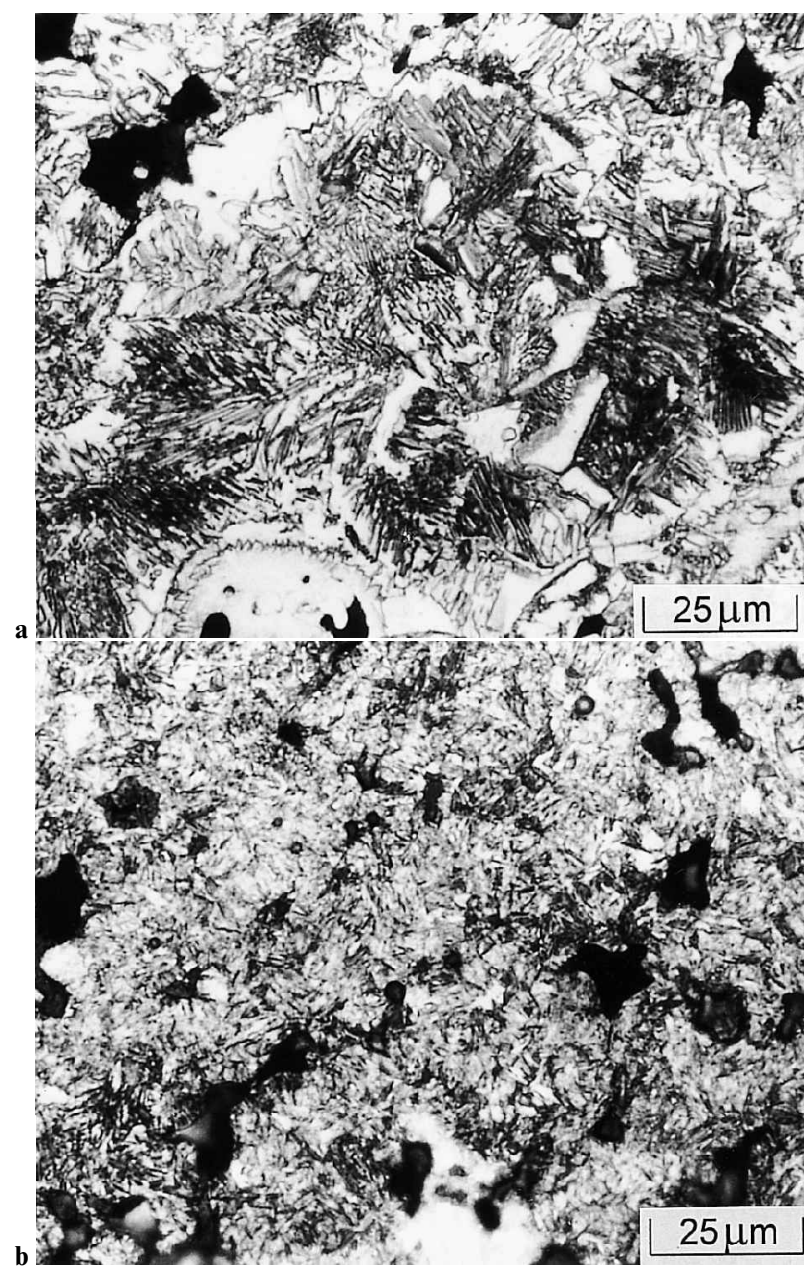

$a$ as sintered; $b$ heat treated

13 Microstructure of pressed $\mathrm{Fe}-1 \cdot 75 \mathrm{Ni}-1 \cdot 5 \mathrm{Cu}-0 \cdot 5 \mathrm{Mo}-$ $0.4 \mathrm{C}$ compact sintered at $1120^{\circ} \mathrm{C}$

the press and sinter specimens (FD-0205) only attained 1170 to $1200 \mathrm{MPa}$, as shown in Table 4. This difference is mainly caused by the difference in the microstructure. In addition to the larger pore size, which deteriorates the mechanical properties, the conventional press and sinter compact consisted of martensite and some pearlite + bainite as a result of inhomogeneous alloying, as shown in Fig. $13 b$. In contrast, the microstructure of the heat treated PIM compact consists mainly of martensite, as shown in Fig. 5.

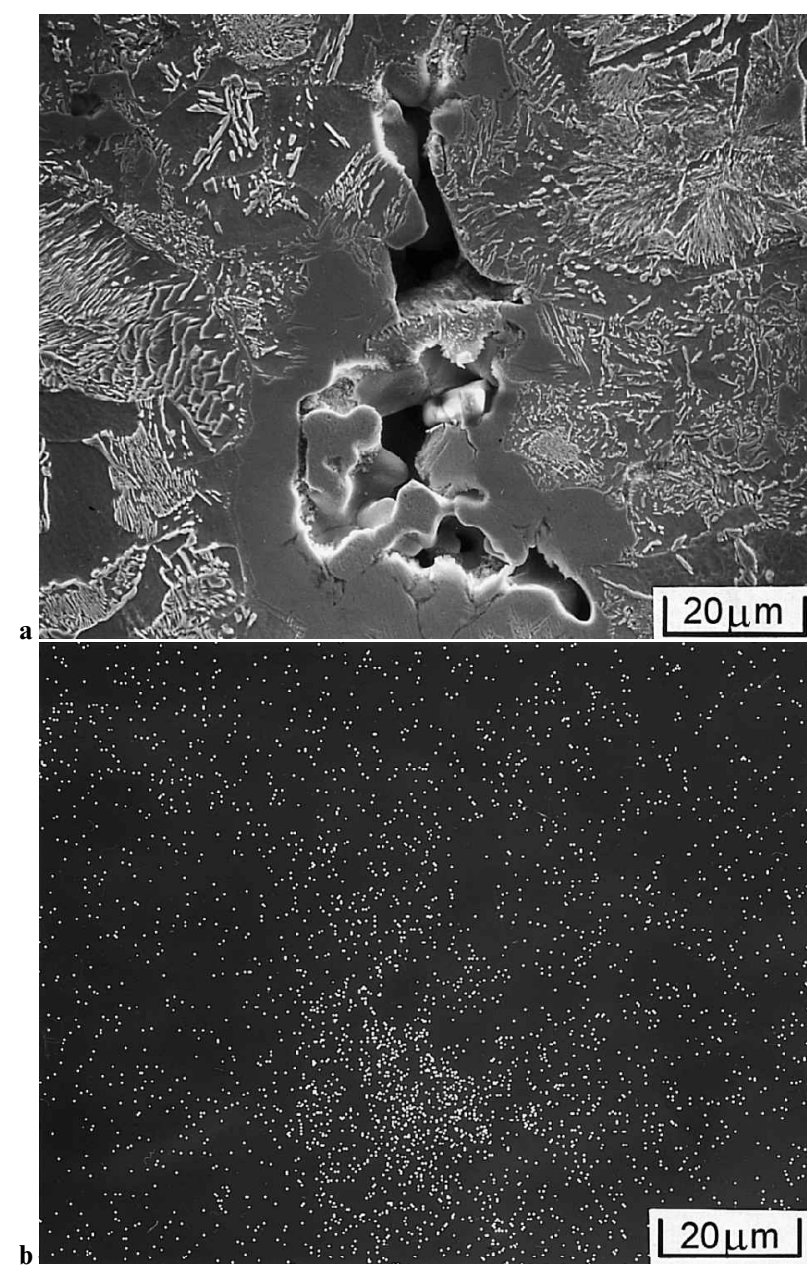

$a$ microstructure; $b$ Ni mapping

14 Nickel mapping shows that nickel content is higher near pore than in bulk

This is because the alloying elements are more homogenised in the PIM compact owing to the finer powders and higher sintering temperatures used.

The high mechanical properties of the alloyed PIM compact could obviously be attributed to the addition of $\mathrm{Ni}$, $\mathrm{Cu}$, and Mo. Among them, nickel is the least homogenised element, as shown in Fig. 3. Table 5 shows that, at $900^{\circ} \mathrm{C}$, Mo has the fastest diffusion rate, followed by $\mathrm{Ni}$ and $\mathrm{Cu}^{2}$ Although copper has a slower diffusion rate into iron than

Table 4 Comparison of mechanical properties of $\mathrm{Fe}-1 \cdot 75 \mathrm{Ni}-1 \cdot 5 \mathrm{Cu}-0 \cdot 5 \mathrm{Mo}-\mathrm{xC}$ compacts made from press and sinter and PIM processes

\begin{tabular}{|c|c|c|c|c|c|c|c|}
\hline & Process & Additives, wt- $\%$ & Source & $\begin{array}{l}\text { Density, } \\
\mathrm{g} \mathrm{cm}^{-3}\end{array}$ & $\begin{array}{l}\text { Tensile } \\
\text { strength, } \\
\mathrm{MPa}\end{array}$ & $\begin{array}{l}\text { Elongation, } \\
\%\end{array}$ & Hardness \\
\hline \multirow[t]{5}{*}{ As sintered* } & PIM & $1 \cdot 75 \mathrm{Ni}-0 \cdot 5 \mathrm{Mo}-1 \cdot 5 \mathrm{Cu}-0 \cdot 4 \mathrm{C}$ & This work & $7 \cdot 36$ & 685 & $7 \cdot 5$ & $91 \mathrm{HRB}$ \\
\hline & PM & $(1.55-1.95) \mathrm{Ni}-(0 \cdot 4-0 \cdot 6) \mathrm{Mo}-(1 \cdot 3-1 \cdot 7) \mathrm{Cu}-(0 \cdot 3-0 \cdot 6) \mathrm{C}$ & Ref. 6 & $7 \cdot 40$ & 690 & $2 \cdot 0$ & $86 \mathrm{HRB}$ \\
\hline & & $1.75 \mathrm{Ni}-0.5 \mathrm{Mo}-1.5 \mathrm{Cu}-0.4 \mathrm{C}$ & Ref. 7 & $7 \cdot 14$ & 558 & 3.7 & $88 \mathrm{HRB}$ \\
\hline & & $1.75 \mathrm{Ni}-0.5 \mathrm{Mo}-1.5 \mathrm{Cu}-0.55 \mathrm{C}$ & Ref. 7 & $7 \cdot 38$ & 779 & $2 \cdot 8$ & $96 \mathrm{HRB}$ \\
\hline & & $1.74 \mathrm{Ni}-0.56 \mathrm{Mo}-1.48 \mathrm{Cu}-0.5 \mathrm{C}$ & Ref. 9 & $7 \cdot 39$ & 790 & $4 \cdot 0$ & $28 \mathrm{HRC}$ \\
\hline \multirow[t]{5}{*}{ Heat treated $\dagger$} & PIM & $1 \cdot 75 \mathrm{Ni}-0.5 \mathrm{Mo}-1 \cdot 5 \mathrm{Cu}-0 \cdot 4 \mathrm{C}$ & This work & $7 \cdot 36$ & 1530 & $<1 \cdot 0$ & $52 \mathrm{HRC}$ \\
\hline & PM & $(1.55-1.95) \mathrm{Ni}-(0.4-0.6) \mathrm{Mo}-(1.3-1 \cdot 7) \mathrm{Cu}-(0.3-0.6) \mathrm{C}$ & Ref. 6 & $7 \cdot 40$ & 1170 & $<1 \cdot 0$ & $45 \mathrm{HRC}$ \\
\hline & & $1.75 \mathrm{Ni}-0.5 \mathrm{Mo}-1.5 \mathrm{Cu}-0.4 \mathrm{C}$ & Ref. 7 & $7 \cdot 16$ & 1030 & $2 \cdot 0$ & $37 \mathrm{HRC}$ \\
\hline & & $1.75 \mathrm{Ni}-0.5 \mathrm{Mo}-1.5 \mathrm{Cu}-0.55 \mathrm{C}$ & Ref. 7 & $7 \cdot 33$ & 1190 & $2 \cdot 0$ & $37 \mathrm{HRC}$ \\
\hline & & $1 \cdot 74 \mathrm{Ni}-0.56 \mathrm{Mo}-1.48 \mathrm{Cu}-0.5 \mathrm{C}$ & Ref. 9 & $7 \cdot 39$ & 1200 & $1 \cdot 0$ & $40 \mathrm{HRC}$ \\
\hline
\end{tabular}

* Sintering for PIM compacts was carried out in $95 \mathrm{~N}_{2}-5 \mathrm{H}_{2}$ at $1200^{\circ} \mathrm{C}$ for $1 \mathrm{~h}$. For PM compacts, sintering was carried out in endothermic gas at $1120^{\circ} \mathrm{C}$ for $30 \mathrm{~min}$.

$\dagger$ Austenised at $850^{\circ} \mathrm{C}$ for $30 \mathrm{~min}$ in argon, quenched in $50^{\circ} \mathrm{C}$ oil, and then tempered at $175^{\circ} \mathrm{C}$ for $60 \mathrm{~min}$. 
Table 5 Volume diffusion rates of $\mathrm{Ni}, \mathrm{Cu}$, and $\mathrm{Mo}$ in iron at $900^{\circ} \mathrm{C}$ (Ref. 27)

\begin{tabular}{llll}
\hline & $\mathrm{Ni}$ & $\mathrm{Cu}$ & $\mathrm{Mo}$ \\
\hline $\mathrm{Dv}, \mathrm{cm}^{2} \mathrm{~s}^{-1}$ & $2.8 \times 10^{-11}$ & $1.3 \times 10^{-11}$ & $1.9 \times 10^{-10}$ \\
\hline
\end{tabular}

nickel, it melts and infiltrates into the interstices among iron powders when the temperature is greater than $1083^{\circ} \mathrm{C}$. This melt flow helps improve the homogenisation. Thus, nickel is the least homogenised element in this alloy.

In addition to the strengthening effect, the alloying elements also influence the sintering behaviour of iron. Figure 7 shows that the straight iron sintered at a faster rate in the $\alpha$ phase than the alloyed system. However, after the phase transformation, the sintering rate decreased significantly. In contrast, the $\mathrm{Fe}-1 \cdot 75 \mathrm{Ni}-1 \cdot 5 \mathrm{Cu}-0 \cdot 5 \mathrm{Mo}$ specimen exhibits less deflection in the shrinkage curve during the phase transformation. This suggests that the alloying elements helped retard the exaggerated grain growth. Thus, with more grain boundaries available for the grain boundary diffusion mechanism to proceed, a higher final sintered density was obtained. Such a sintering behaviour has also been found in the $\mathrm{Fe}-\mathrm{Ni}$ alloy system. ${ }^{10}$ Hwang and Shiao reported that nickel forms a coating on iron powders during heating through surface diffusion. Such coating inhibits the sintering of iron at low temperatures. This impeded densification was also found in this study by comparing the shrinkage curves of the alloy and straight iron shown in Fig. 7. With a low density, highly porous structure, and small necks, the grain boundary migration away from interparticle necks becomes more difficult. Thus, when the $\alpha \rightarrow \gamma$ phase transformation occurs, the exaggerated grain growth become less severe. When carbon is present, the exaggerated grain growth is also impeded at low temperatures, as shown in Fig. 6. This is because carbon lowers the phase transformation temperature to $740^{\circ} \mathrm{C}$, at which point the neck size is still small. With small necks and the temperature at $740^{\circ} \mathrm{C}$, the exaggerated grain growth during the phase transformation becomes limited. Thus, in both cases, when carbon and alloying elements are present, the shrinkage curves become smoother and high final sintered densities are attained.

\section{CONCLUSIONS}

The mechanical properties of powder injection moulded specimens made with a $\mathrm{Fe}-1 \cdot 75 \mathrm{Ni}-0 \cdot 5 \mathrm{Mo}-1 \cdot 5 \mathrm{Cu}-0 \cdot 4 \mathrm{C}$ alloy were investigated. The compacts which were sintered at $1200^{\circ} \mathrm{C}$ show tensile strength, hardness, and elongation readings of $685 \mathrm{MPa}, 91 \mathrm{HRB}$, and $7 \cdot 5 \%$, respectively. The strength and hardness are similar to those of the press and sinter counterparts, except that the elongation is much improved. After heat treatment, the tensile strength of the PIM specimen increased to $1530 \mathrm{MPa}$, compared with the $1200 \mathrm{MPa}$ attained using the conventional PM process. These improvements are attributed to the better alloy homogenisation and finer grain size in the microstructure.

It was found that the intrinsic carbon in the iron powder significantly decreased the $\alpha \rightarrow \gamma$ phase transformation temperature to $740^{\circ} \mathrm{C}$ and hindered the exaggerated grain growth which usually occurs during the phase transformation at $912^{\circ} \mathrm{C}$. The alloying additives also inhibit the exaggerated grain growth, but to a lesser extent. Among the three metallic additives, Mo has the fastest homogenisation rate, followed by $\mathrm{Cu}$ and $\mathrm{Ni}$.

\section{ACKNOWLEDGEMENTS}

The authors wish to thank H. C. Starck Co. for donating the molybdenum powder. They also wish to thank ChinChih Metal Industrial Co. for supplying the press and sinter FD-0205 parts.

\section{REFERENCES}

1. 'Materials standards for metal injection moulded parts', 12-13; 2000, Princeton, NJ, MPIF.

2. M. BLÖMACHER, D. WEINAND, M. SCHWARZ, and E. LANGER: 'Advances in powder metallurgy and particulate materials', (ed. A. Lawley and A. Swanson), 5.73-5.89; 1993, Princeton, NJ, MPIF

3. H. MIURA, T. HONDA, K. F. HENS, and R. M. GERMAN: in 'Powder injection moulding symposium', (ed. P. Booker et al.), 203-217; 1992, Princeton, NJ, MPIF

4. P. A. HAUCK, P. M. MACHMEIER, P. A. DEPOUTILOFF, P. B. LEMENS, and W. R. MOSSNER: 'Advances in powder metallurgy and particulate materials', (ed. L. F. Pease III and R. J. Sansoucy), 2.237-2.257; 1991, Princeton, NJ, MPIF.

5. F. PETZOLDT, H. EIFERT, T. HARTWIG, and G. VELTL: 'Advances in powder metallurgy and particulate materials', (ed. M. Phillips and J. Porter), 6.3-6.13; 1995, Princeton, NJ, MPIF

6. 'Materials standards for PM structural parts', 47; 2000, Princeton, NJ, MPIF.

7. 'Computer aided selection of iron powders', 1995, Höganäs, Höganäs AB.

8. M. GAgNe and y. TRUdel: Met. Powder Rep., 1992, 47, (2), 36-41.

9. M. KHALEGHI and R. HAYNES: Powder Metall. Int., 1988, 20, (1), 9-12.

10. K. S. HWANG and M. Y. HSIAO: Metall. Mater. Trans. B, 1996, 27B, 203-211.

11. H. ZHANG and R. M. GERMAN: Int. J. Powder Metall., 1991, 27, (3), 249-254.

12. Y. HANATATE, K. MAJIMA, and H. MitAni: Trans. Jpn Inst. Met., 1978, 19, 669-673

13. Y. hanatate, K. MaJima, and H. Mitani: J. Jpn Inst. Met., 1976 , 40, (10), 1010-1015.

14. K. LiPP, G. STRAFFELINI, and C. M. SONSINO: Powder Metall. Int., 1993, 25, (6), 261-266.

15. J. A. LUND and A. M. LAWSOn: Trans. Metall. Soc. AIME, 1966, 236, 581-582.

16. E. HORnBogen and R. C. GLENN: Trans. Metall. Soc. AIME, 1960, 218, 1064-1070.

17. C. T. HUANG and K. S. HWANG: Powder Metall., 1996 39, (2), 119-123.

18. F. V. LENEL and K. S. HWANG: Powder Metall. Int., 1980, 12, (2), 88-90.

19. S. Kohara and K. Tatsuzawa: J. Jpn Soc. Powder Powder Metall., 1986, 33, 139-145.

20. H. DANninger: Powder Metall. Int., 1992, 24, (2), 73-79.

21. H. DANNINGER: Powder Metall. Int., 1992, 24, (3), 163-168.

22. M. HAMIUDDIN: Powder Metall. Int., 1983, 15, (3), 147-150.

23. Y. L. HO and S. T. LIN: Metall. Mater. Trans. A, 1995, 26A, 133-142.

24. M. A. PHILLIPS, E. L. STREICHER, MELVIN RENOWDEN, R. M. GERMAN, and J. M. FRIEDT: 'Powder injection moulding symposium', (ed. P. Booker et al.), 203-217; 1992, Princeton, NJ, MPIF.

25. G. Cizeron and P. Lacombe: C. R. Acad. Bulg. Sci., 1955, 241, 409-410.

26. H. ZhANG, R. M. GeRman, K. F. Hens, and D. LeE: Powder Metall. Int., 1990, 22, (6), 15-18.

27. S. MROWEC: 'Defects and diffusion in solids, an introduction', 400; 1974, New York, NY, Elsevier/North-Holland Inc. 